\title{
The Influence of Shelter, Conspecifics, and Threat of Predation on the Behavior of the Long-Spined Sea Urchin (Diadema antillarum)
}

\author{
Meredith D. Kintzing \\ Old Dominion University \\ Mark J. Butler IV \\ Old Dominion University, mbutler@odu.edu
}

Follow this and additional works at: https://digitalcommons.odu.edu/biology_fac_pubs

Part of the Marine Biology Commons

\section{Repository Citation}

Kintzing, Meredith D. and Butler, Mark J. IV, "The Influence of Shelter, Conspecifics, and Threat of Predation on the Behavior of the Long-Spined Sea Urchin (Diadema antillarum)" (2014). Biological Sciences Faculty Publications. 4.

https://digitalcommons.odu.edu/biology_fac_pubs/4

\section{Original Publication Citation}

Kintzing, M.D., \& Butler, M.J. (2014). The influence of shelter, conspecifics, and threat of predation on the behavior of the long-spined sea urchin (Diadema antillarum). Journal of Shellfish Research, 33(3), 781-785. doi: 10.2983/035.033.0312 


\section{The Influence of Shelter, Conspecifics, and Threat of Predation on the Behavior of the Long-Spined Sea Urchin (Diadema antillarum)}

Author(s): Meredith D. Kintzing and Mark J. Butler IV

Source: Journal of Shellfish Research, 33(3):781-785.

Published By: National Shellfisheries Association

DOI: http://dx.doi.org/10.2983/035.033.0312

URL: http://www.bioone.org/doi/full/10.2983/035.033.0312

BioOne (www.bioone.org) is a nonprofit, online aggregation of core research in the biological, ecological, and environmental sciences. BioOne provides a sustainable online platform for over 170 journals and books published by nonprofit societies, associations, museums, institutions, and presses.

Your use of this PDF, the BioOne Web site, and all posted and associated content indicates your acceptance of BioOne's Terms of Use, available at www.bioone.org/page/terms_of_use.

Usage of BioOne content is strictly limited to personal, educational, and non-commercial use. Commercial inquiries or rights and permissions requests should be directed to the individual publisher as copyright holder. 


\title{
THE INFLUENCE OF SHELTER, CONSPECIFICS, AND THREAT OF PREDATION ON THE BEHAVIOR OF THE LONG-SPINED SEA URCHIN (DIADEMA ANTILLARUM)
}

\author{
MEREDITH D. KINTZING AND MARK J. BUTLER IV* \\ Department of Biological Sciences, Old Dominion University, Norfolk, VA 23529
}

\begin{abstract}
The interplay of competition and predation often affects prey habitat use, which may concentrate prey in safer areas with indirect consequences on their foraging efficiency and the effects of their foraging on the community. Predation is intense on coral reefs where competition for limited space and food is severe. The sea urchin Diadema antillarum, an inhabitant of Caribbean coral reefs, uses crevice shelters and often aggregates with conspecifics for protection against predators, which appears to reflect a conflicting balance between group defense versus competition for limited shelter. A series of laboratory experiments was used to determine how the availability of shelter, conspecifics, and chemical odors from conspecifics and a predator-the spotted spiny lobster (Panulirus guttatus) — affect D. antillarum shelter use. The long-spined sea urchin D. antillarum responded strongly to the odor of conspecifics and the lobster predator. Absent the threat of predation, D. antillarum compete for shelter and avoid shelters bearing the scent of other urchins. But, D. antillarum readily shared shelters and preferred the scent of conspecifics when exposed to lobster odors. Thus, efforts to enhance the recovery of $D$. antillarum populations on degraded reefs must strike a balance between minimizing their mortality from predation and increasing habitat complexity, which not only increases shelter for $D$. antillarum, but also their predators.
\end{abstract}

KEY WORDS: sea urchin, Diadema antillarum, habitat complexity, ideal free distribution, predation threat, coral reefs

\section{INTRODUCTION}

Predators can shape the taxonomic structure of animal communities and control the abundance of prey (Hairston et al. 1960, Paine 1966). In turn, prey have evolved physical (Hoverman et al. 2005), chemical (Bolser \& Hay 1996), and behavioral adaptations that limit their vulnerability to predation (Trussell et al. 2003, Smee \& Weissburg 2008) and, in some cases, combine these strategies to reduce predation risk. For example, the sharp, sometimes toxic spines of sea urchins provide both physical and chemical deterrence to predation, but urchins have also evolved a number of defensive behaviors to avoid predators (Vadas \& Elner 2003). Sea urchins have well developed olfactory senses, and many species flee or curtail feeding in response to chemical cues produced by predators and injured conspecifics (Snyder \& Snyder 1970, Freeman 2006, Matassa 2010). Antipredatory adaptations such as these provide obvious evolutionary advantages to prey, but often come at a cost, such as reduced foraging or restriction to suboptimal habitats where their growth or fecundity is compromised by overcrowding (Katz \& Dill 1998).

This Faustian dilemma - enhanced competition in resourcepoor habitats versus greater risk of predation - is embodied in Fretwell's ideal free distribution theory (Fretwell \& Lucas 1970), an outgrowth of optimal foraging theory first developed to explore how trade-offs in competitive ability and predation risk impact resource use (MacArthur \& Pianka 1966). Although Fretwell's original theory examined how organism density, a proxy for competition, affects habitat quality, others have extended the idea to examine how the threat of predation concentrates prey in safer areas and thus indirectly impacts habitat quality (Grand \& Dill 1999, Heithaus et al. 2007, Heithaus et al. 2009). Many of these studies confirm Connell's idea (Connell 1975) that the threat of predation usually trumps the disadvantages of increased interspecific competition in

*Corresponding author. E-mail: mbutler@odu.edu DOI: $10.2983 / 035.033 .0312$ mediating habitat selection and resource use (Heithaus et al. 2007, Heithaus et al. 2009). This ecological trade-off is common in tropical marine ecosystems.

Predation is intense in low-latitude, high-diversity ecosystems such as coral reefs (Bertness et al. 1981, Menge \& Lubchenco 1981, Bolser \& Hay 1996,) where competition for limited space and food is also severe (Jackson \& Buss 1975, Williams 1981, Connell et al. 2004). The sea urchin Diadema antillarum, which inhabits the coral reefs of the tropical Caribbean, offers a case in point. It uses crevice shelters and often aggregates with conspecifics for protection against predators (Carpenter 1984, Lee 2006, Miller et al. 2007). This may reflect the conflicting balance between group defense for protection versus competition for limited quality habitats. The sea urchin $D$. antillarum was used as a model organism in a series of laboratory experiments to examine how the availability of shelter and conspecifics affect $D$. antillarum behavior in the presence and absence of a common predator, the spotted spiny lobster (Panulirus guttatus).

\section{MATERIALS AND METHODS}

All the experiments described were conducted at the Goshen College Marine Laboratory on Long Key, Florida, from July 2008 through October 2009. Unless otherwise noted, experiments were conducted in 200-L flow-through seawater tanks and ran for approximately $24 \mathrm{~h}$ under natural photoperiod and ambient seawater temperatures (range, $27-31^{\circ} \mathrm{C}$ ) and salinity (range, 32-36 ppt). Experimental setups that included head tanks had natural, sand-filtered seawater flowing to a $20-\mathrm{L}$ head tank. Seawater then flowed from each head tank at approximately $1 \mathrm{~L} / \mathrm{min}$ through plastic airline tubing to a shelter below. All experimental shelters were constructed with 3 stacked masonry bricks soaked previously in seawater. Sea urchins (Diadema antillarum) and lobsters (Panulirus guttatus) used in the experiments were collected from nearby reef habitats by divers and returned to those reefs at the conclusion of these studies. 


\section{Effect of Conspecifics on Diadema Shelter Choice}

Three separate experiments were conducted to investigate the effects of conspecifics on shelter use by Diadema antillarum; specifically, shelter choice was tested with (1) conspecifics present and shelter not limited, (2) conspecific odors present and shelter not limited, and (3) conspecific odors present and shelter limited. To determine whether the presence of a conspecific affects shelter selection by $D$. antillarum, $2 \mathrm{D}$. antillarum were added to an experimental tank containing 2 shelters. The choice of the D. antillarum to shelter together or apart was recorded after $24 \mathrm{~h}$ $(n=26)$ and was tested using Fisher's exact test.

Also tested was whether the choice, by Diadema antillarum, of a shelter with or without a conspecific was controlled by conspecific odors. To do so, a single $D$. antillarum was placed in an experimental tank with two shelters. Seawater from 2 head tanks - 1 empty head tank (i.e., the seawater control) and 1 containing a single $D$. antillarum (test diameter, $30-50 \mathrm{~mm}$ ) - flowed to separate shelters. At the conclusion of the experiment $24 \mathrm{~h}$ later, the shelter selected by D. antillarum was recorded $(n=21)$. Fisher's exact test was used to determine whether $D$. antillarum was attracted to 1 shelter over the other.

To determine whether shelter limitation influences whether Diadema antillarum will co-occupy a shelter with a conspecific, a single $D$. antillarum was added to a tank with a single shelter. Water from a head tank containing a single $D$. antillarum (test diameter, $30-50 \mathrm{~mm}$ ) flowed to the shelter. Whether the $D$. antillarum used the shelter $(n=21)$ was recorded and tested with Fisher's exact test.

\section{Diadema Shelter Choice in the Presence of Predator Odor}

The sea urchin Diadema co-occur on coral reefs with predatory lobsters, so the importance of urchin shelter use in the presence of a predatory odor was examined. A single D. antillarum was added to an experimental tank with 1 shelter into which water flowed from a head tank containing a single lobster (Panulirus guttatus; carapace length, 45-55 mm). After $24 \mathrm{~h}$, whether the $D$. antillarum used the shelter $(n=18)$ was tested with a Fisher's exact test.

\section{Effect of Predator and Conspecific Odors on Diadema Shelter Choice}

Last, shelter choice by Diadema antillarum when given the preference between 2 shelters from which flowed either a conspecific or a predator chemical cue was tested. Each of the 2 shelters received seawater from 1 of 2 head tanks - 1 containing a single Panulirus guttatus (carapace length, 45-55 $\mathrm{mm}$ ) and the other containing a single $30-50-\mathrm{mm}$ (test diameter) $D$. antillarum. One $D$. antillarum was then added to the experimental tank. At the conclusion of the experiment, which shelter the urchin selected was recorded $(n=19)$ and Fisher's exact test was used to examine the results.

\section{RESULTS}

\section{Effect of Conspecifics on Diadema Shelter Choice}

When 2 Diadema antillarum were given the choice to shelter together or separately with no threat of predation and when shelter was not limiting, they occupied separate shelters more frequently than together ( $n=26, P=0.002$; Fig. 1A).
The sea urchin Diadema antillarum also avoided shelters from which flowed a conspecific odor only $(n=21, P=0.034$; Fig. 1B). The size of $D$. antillarum did not affect these results; the 5 individuals that chose the shelter with a conspecific odor spanned the size range of the D. antillarum tested. This result is consistent with the outcome of the previous experiment (see Fig. 1A) and demonstrates that $D$. antillarum use olfaction to detect and avoid conspecifics.

When only 1 shelter was available, Diadema antillarum sometimes sheltered in dens from which flowed a chemical cue of a conspecific. However, they were just as often found alone outside the shelter ( $n=21, P>0.99$; Fig. 1C).

\section{Shelter Choice by Diadema in the Presence of Predator Odor}

When shelter was limited and the only available shelter contained a waterborne predator cue, Diadema antillarum just as often remained in the open outside a shelter as entered a shelter producing the scent of the predator Panulirus guttatus ( $n=18, P>0.99$; Fig. 1D).

\section{Shelter Choice by Diadema with Both Predator and Conspecific Odors}

When given the choice between using a shelter with either a conspecific odor or that of a potential predator, Diadema antillarum more often selected the shelter with the conspecific odor than the predatory cue ( $n=19, P=0.011$; Fig. 1E).

\section{DISCUSSION}

Several studies have examined the independent effects of shelter and reef complexity, predators, and conspecifics on Diadema antillarum behavior (Carpenter 1984, Lee 2006, Miller et al. 2007, Clemente \& Hernández 2008, ), but this is the first to examine all 3 concurrently. Laboratory results indicate that D. antillarum are, first and foremost, attracted to shelter, although chemically mediated responses to conspecifics and predators also strongly influences $D$. antillarum shelter use. The presence of conspecifics deters aggregation among $D$. antillarum, but when the threat of predation occurs, D. antillarum aggregate within available shelter, indicating a trade-off between reduced predation risk and competition.

The laboratory results are consistent with field observations of decreased movement and foraging by Diadema antillarum in predator-rich environments (Carpenter 1984), and they support the theory that reduced predation risk comes at the cost of lost foraging opportunities. The sea urchin D. antillarum often aggregate in crevices on reefs and, after they locate a suitable shelter, they move only at night and only short distances from that "home shelter," which appears to enhance their survival - especially that of juveniles (Randall et al. 1964, Miller et al. 2007). But this behavior, which prioritizes protection from day-active predators over food acquisition, impacts their growth, fecundity, and survivorship negatively (Levitan 1988, Levitan 1989). The results indicate that interactions with conspecifics and at least 1 confirmed predator, the spotted lobster Panulirus guttatus, are driven by chemical cues. Thus, even the threat of predation acquired via olfaction is sufficient to decrease the fitness of D. antillarum. 

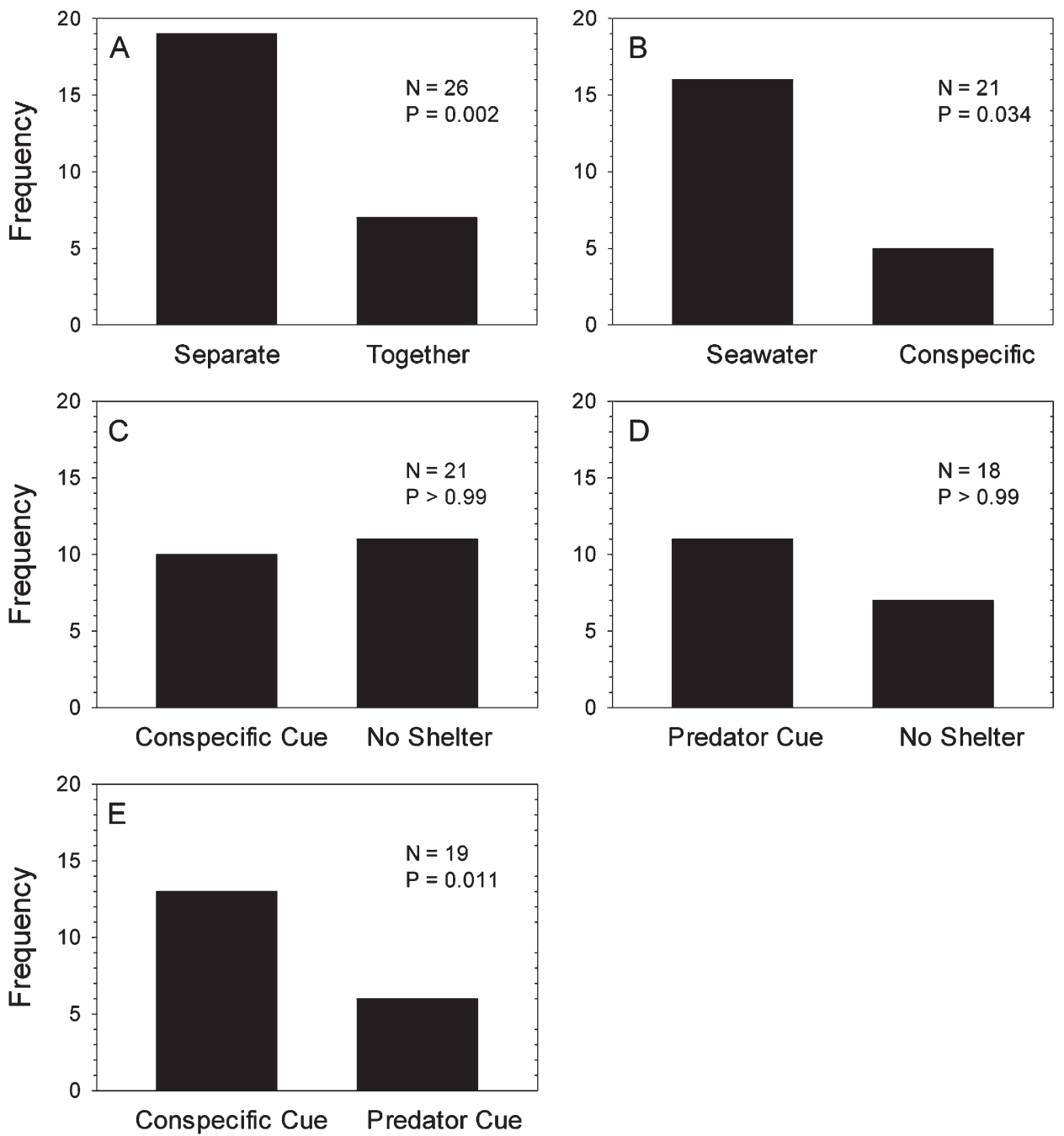

Figure 1. (A) Shelter use by 2 Diadema antillarum when offered 2 shelters and no predator odor. (B) Shelter choice by $D$. antillarum between shelters containing a seawater control cue or a conspecific waterborne chemical cue. (C) Shelter use by $D$. antillarum when a conspecific odor is present and shelter is limited. (D) Shelter use by $D$. antillarum when a predator odor is present and shelter is limited. (E) Shelter choice by $D$. antillarum when conspecific and predator odors are present.

Under natural circumstances, large fish and invertebrate predators of urchins are abundant on coral reefs and thus drive urchins to shelter with conspecifics. However, overfishing on Caribbean reefs is rampant (Dulvy et al. 2004, Aronson \& Precht 2006). It may be no coincidence that Diadema antillarum populations have recovered from the massive die-off of the 1980s more quickly in areas where overfishing is particularly severe (Harborne et al. 2009) and on nearshore reefs where sea urchins often recruit and large predators are more easily accessed by fishermen.

Caribbean coral reefs are also becoming less structurally complex as a result of the loss of scleractinian corals from bleaching, disease, and algal overgrowth (Alvarez-Filip et al. 2009, Kennedy et al. 2013). Ocean acidification is expected to exacerbate this phenomenon (Hoegh-Guldburg et al. 2007). This "flattening" of coral reefs has serious implications for the recovery of Diadema antillarum populations in light of these results and those of other studies (Hereu et al. 2005, Lee 2006, Clemente \& Hernández 2008), which demonstrate that
D. antillarum abundance is greatest in structurally complex environments (Lee 2006, Clemente \& Hernández 2008) - a pattern shared with reef fishes (Gratwicke \& Speight 2005, Ledlie et al. 2007, Alvarez-Filip et al. 2009). Populations of $D$. antillarum are already subject to intense predation pressure, and further loss of habitat structural complexity will likely exacerbate those losses (Chiappone et al. 2002, Miller et al. 2009, Harborne et al. 2009, Kintzing \& Butler 2014). Therefore, recovery of $D$. antillarum populations and the associated recovery of algal-dominated reefs as a result of $D$. antillarum grazing (Edmunds \& Carpenter 2001, Carpenter \& Edmunds 2006, Idjadi et al. 2010) may require not only D. antillarum stock enhancement (Macía et al. 2007), but also supplementation of crevice shelters of various sizes (Lee 2006, Gratwicke \& Speight 2005). Paradoxically, increased habitat complexity also often increases the abundance and diversity of urchin predators (Mattila et al. 2008), which in turn will constrain foraging by $D$. antillarum and limit their importance in reef recovery. It will thus be necessary to determine the right balance between 
enhancement of coral reef structure and urchin stocks to achieve the hoped for gains in coral reef recovery.

\section{ACKNOWLEDGMENTS}

The authors gratefully acknowledge funding for this research from PADI Project Aware, the PADI Foundation, Mote Protect
Our Reefs Program, the Old Dominion University Dominion Scholars Program, Florida Sea Grant (R/LR-B-61), and the National Science Foundation (BIO OCE - 0452383). We also thank D. Smith, A. Mojica, J. Brown, N. Silbiger, and D. Behringer for assistance in the field. The project and manuscript were greatly improved by insightful comments from I. Bartol, D. Dauer, R. Steneck, and A. Savitzky.

\section{LITERATURE CITED}

Aronson, R. B. \& W. Precht. 2006. Conservation, precaution, and Caribbean reefs. Coral Reefs 25:441-450.

Alvarez-Filip, L., N. K. Dulvy, J. A. Gill, I. M. Côté \& A. R. Watkinson. 2009. Flattening of Caribbean coral reefs: region-wide declines in architectural complexity. Proc. R. Soc. B 276:3019-3025.

Bertness, M. D., S. D. Garrity \& S. C. Levings. 1981. Predation pressure and gastropod foraging: a tropical-temperate comparison. Evolution 35:995-1007.

Bolser, R. C. \& M. E. Hay. 1996. Are tropical plants better defended? Palatability and defenses of temperate and tropical seaweeds. Ecology 77:2269-2286.

Carpenter, R. C. 1984. Predator and population density control of homing behavior in the Caribbean echinoid Diadema antillarum. Mar. Biol. 82:101-108.

Carpenter, R. C. \& P. J. Edmunds. 2006. Local and regional scale recovery of Diadema promotes recruitment of scleractinian corals. Ecol. Lett. 9:268-277.

Chiappone, M., D. W. Swanson, S. L. Miller \& S. G. Smith. 2002. Large-scale surveys of the Florida Reef Tract indicate poor recovery of the long-spined sea urchin Diadema antillarum. Coral Reefs $21: 155-159$

Clemente, S. \& J. C. Hernández. 2008. Influence of wave exposure and habitat complexity in determining spatial variation of the sea urchin Diadema aff. antillarum (Echinoidea: Diadematidea) populations and macroalgal cover (Canary Islands-eastern Atlantic Ocean). Int. J. Trop. Biol. 56:229-254.

Connell, J. H. 1975. Some mechanisms producing structure in natural communities: a model and evidence from field experiments. In: M. L. Cody \& J. M. Diamond, editors. Ecology and evolution of communities. Cambridge, MA: Harvard University Press. p. 460-490.

Connell, J. H., T. P. Hughes, C. C. Wallace, J. E. Tanner, K. E. Harms \& A. M. Kerr. 2004. A long-term study of competition and diversity of corals. Ecol. Monogr. 74:179-210.

Dulvy, N. K., R. P. Freckleton \& N. V. C. Polunin. 2004. Coral reef cascades and the indirect effects of predator removal by exploitation. Ecol. Lett. 7:410-416.

Edmunds, P. J. \& R. C. Carpenter. 2001. Recovery of Diadema antillarum reduces macroalgal cover and increases abundance of juvenile corals on a Caribbean reef. Proc. Natl. Acad. Sci. USA 98:5067-5071.

Freeman, A. 2006. Size-dependent trait-mediated indirect interactions among sea urchin herbivores. Behav. Ecol. 17:182-187.

Fretwell, S. D. \& H. L. Lucas, Jr. 1970. On territorial behavior and other factors influencing habitat distribution in birds: I. Theoretical development. Acta Biotheor. 19:16-36.

Grand, T. C. \& L. M. Dill. 1999. The effect of group size on the foraging behavior of juvenile Coho salmon: reduction of predation risk or increased competition? Anim. Behav. 58:443-451.

Gratwicke, B. \& M. R. Speight. 2005. Effects of habitat complexity on Caribbean marine fish assemblages. Mar. Ecol. Prog. Ser. 292:301-310.

Hairston, N. G., F. E. Smith \& L. B. Slobodkin. 1960. Community structure, population control, and competition. Am. Nat.91:421-425.

Harborne, A. R., P. G. Renaud, E. H. M. Tyler \& P. J. Mumby. 2009. Reduced density of the herbivorous urchin Diadema antillarum inside a Caribbean marine reserve linked to increased predation pressure by fishes. Coral Reefs 28:783-791.

Heithaus, M. R., A. Frid, A. J. Wirsing, L. M. Dill, J. W. Fourqurean, D. Burkholder, J. Thomson \& L. Bejder. 2007. State-dependent risktaking by green sea turtles mediates top-down effects of tiger shark intimidation in a marine ecosystem. J. Anim. Ecol. 76:837-844.

Heithaus, M. R., A. J. Wirsing, D. Burkholder, J. Thomson \& L. M. Dill. 2009. Towards a predictive framework for predator risk effects: the interaction of landscape features and prey escape tactics. J. Anim. Ecol. 78:556-562.

Hereu, B., M. Zabala, C. Linares \& E. Sala. 2005. The effects of predator abundance and habitat structural complexity on survival of juvenile sea urchins. Mar. Biol. 146:293-299.

Hoegh-Guldburg, O., P. J. Mumby, A. J. Hooten, R. S. Steneck, P. Greenfield, E. Gomez, C. D. Harvell, P. F. Sale, A. J. Edwards, K. Caldeira, N. Knowlton, C. M. Eakin, R. Iglesias-Prieto, N. Muthiga, R. H. Bradbury, A. Dubi \& M. E. Hatziolos. 2007. Coral reefs under rapid climate change and ocean acidification. Science 318:345-346.

Hoverman, J. T., J. R. Auld \& R. A. Relyea. 2005. Putting prey back together again: integrating predator-induced behavior, morphology, and life history. Oecologia 144:481-491.

Idjadi, J. A., R. N. Haring \& W. F. Precht. 2010. Recovery of the sea urchin Diadema antillarum promotes scleractinian coral growth and survivorship on shallow Jamaican reefs. Mar. Ecol. Prog. Ser. 403:91-100.

Jackson, J. B. C. \& L. Buss. 1975. Allelopathy and spatial competition among coral reef invertebrates. Proc. Natl. Acad. Sci. USA 72:51605163.

Katz, L. B. \& L. M. Dill. 1998. The scent of death: chemosensory assessment of predation risk by animals. Ecoscience 5:361-394.

Kennedy, E. V., C. T. Perry, P. R. Halloran, R. Iglesias-Prieto, C. H. L. Schoneberg, M. Wisshak, A. U. Form, J. P. Carricart-Ganivet, M. Fine, C. M. Eakin \& P. J. Mumby. 2013. Avoiding coral reef functional collapse requires local and global action. Curr. Biol. 23:912-918.

Kintzing, M. D. \& M. J. Butler, IV. 2014. Effects of predation upon the long-spined sea urchin (Diadema antillarum) by the spotted spiny lobster (Panulirus guttatus). Mar. Ecol. Prog. Ser. 485:185-191.

Ledlie, M. H., N. A. J. Graham, J. C. Bythell, S. K. Wilson, S. Jennings, N. V. C. Polunin \& J. Hardcastle. 2007. Phase shifts and the role of herbivory in the resilience of coral reefs. Coral Reefs 26:641-653.

Lee, S. C. 2006. Habitat complexity and consumer-mediated positive feedbacks on a Caribbean coral reef. Oikos 112:442- 447.

Levitan, D. R. 1988. Density-dependent size regulation and negative growth in the sea urchin Diadema antillarum Philippi. Oecologia 76:627-629.

Levitan, D. R. 1989. Density-dependent size regulation in Diadema antillarum: effects on fecundity and survivorship. Ecology 70:14141424.

MacArthur, R. H. \& E. R. Pianka. 1966. On optimal use of a patchy environment. Am. Nat. 100:603-609.

Macía, S., M. P. Robinson \& A. Nalevanko. 2007. Experimental dispersal of recovering Diadema antillarum increases grazing 
intensity and reduces macroalgal abundance on coral reefs. Mar. Ecol. Prog. Ser. 348:173-182.

Matassa, C. M. 2010. Purple sea urchins Strongylocentrotus purpuratus reduce grazing rates in response to risk cues from the spiny lobster Panulirus interruptus. Mar. Ecol. Prog. Ser. 400:283-288.

Mattila, J., K. L. Heck, Jr., E. Millstein, E. Miller, C. Gustafsson, S. Williams \& D. Byron. 2008. Increased habitat structure does not always provide increased refuge from predation. Mar. Ecol. Prog. Ser. 361:15-20.

Miller, M. W., K. L. Kramer, S. M. Williams, L. Johnston \& A. M. Szmant. 2009. Assessment of current rates of Diadema antillarum larval settlement. Coral Reefs 28:511-515.

Menge, B. A. \& J. Lubchenco. 1981. Community organization in temperate and tropical rocky intertidal habitats: prey refuges in relation to consumer pressure gradients. Ecol. Monogr. 51:429-450.

Miller, R. J., A. J. Adams, J. P. Ebersole \& E. Ruiz. 2007. Evidence for positive density-dependent effect in recovering Diadema antillarum populations. J. Exp. Mar. Biol. Ecol. 349:215-222.
Paine, R. T. 1966. Food web complexity and species diversity. Am. Nat. 100:65-75.

Randall, J. E., R. E. Schroeder \& W. A. Starck, II. 1964. Notes on the biology of the echinoid Diadema antillarum. Caribb. J. Sci. 4:421433.

Smee, D. L. \& M. J. Weissburg. 2008. Heightened prey responses in risky habitats: predation pressure increases prey sensitivity to predation risk. Mar. Ecol. Prog. Ser. 363:39-50.

Snyder, N. \& H. Snyder. 1970. Alarm response of Diadema antillarum. Science 168:276-278.

Trussell, G. C., P. J. Ewanchuk \& M. D. Bertness. 2003. Trait-mediated effects in intertidal food chains: predator risk cues alter prey feeding rates. Ecology 84:629-640.

Vadas, R. L., Sr. \& R. W. Elner. 2003. Response to predation cues and food in two species of sympatric, tropical sea urchins. Mar. Ecol. (Berl.) 24:101-121.

Williams, A. H. 1981. An analysis of competitive interactions in a patch back-reef environment. Ecology 62:1107-1120. 